\title{
CLASSROOM ASSESSMENT: BAGIAN INTEGRAL PROSES PEMBELAJARAN KEJURUAN DALAM UPAYA MENYIAPKAN TENAGA KERJA SECARA HOLISTIK
}

\author{
Wagiran \\ Jurusan Pendidikan Teknik Mesin FT UNY \\ Kampus Karangmalang Yogyakarta 55281 \\ wa_giran@yahoo.com
}

\begin{abstract}
Abstrak: Asesmen kemampuan siswa pendidikan kejuruan sudah saatnya mengalami perubahan. Hal ini disebabkan tuntutan dunia kerja yang memerlukan pengetahuan dan kemampuan baru. Dalam era ekonomi global di abad 21, siswa tidak hanya membutuhkan kemampuan dasar tetapi juga kemampuan berpikir kritis, analisis dan membuat inferensi. Untuk meningkatkan kompetensi tersebut dibutuhkan perubahan dalam hal asesmen baik dalam level sekolah maupun kelas. Classroom assessment merupakan upaya efektif dalam upaya meningkatkan kualitas pembelajaran untuk mencapai tujuan dihasilkannya lulusan yang memiliki kemampuan kognitif, afektif dan psikomotorik secara holistik sesuai tuntutan SDM dalam era global.
\end{abstract}

Kata kunci: asesmen kelas, pendidikan kejuruan, holistik.

\begin{abstract}
Assessment of student achievement needs to change, largely because today's students face a world that will demand new knowledge and abilities. In the global economy of the $21^{\text {st }}$ century, students not only need to understand the basics, but also to think critically, to analyze, and to make inferences. In order to develop these skills, changes in assessment at school and classroom level are required. Classroom assessment is an effective strategy to improve the quality of learning to achieve the goals of creating graduates with holistic mastery of cognitive, affective, and psychomotor ability, according to the demands of human resources in the global era.
\end{abstract}

Keywords: classroom assessment, learning, vocational education

\section{PENDAHULUAN}

Tantangan dunia pendidikan khususnya dalam penyiapan tenaga kerja ke depan semakin kompleks. Secara umum dunia kerja di masa yang akan datang ditandai oleh ketidakpastian, semakin cepat dan sering berubah, dan menuntut fleksibilitas yang lebih besar. Perubahan ini secara mendasar tidak saja menuntut angkatan kerja yang memiliiki kemampuan dasar yang semakin kuat, tetapi juga menuntut kemampuan mendemonstrasikan penguasaan kognitif yang lebih, pemecahan masalah dan bekerja kolaboratif (Sukamto, 2001). Dalam kaitan dengan masa depan dunia kerja yang penuh ketidakpastian diperlukan kemampuan seseorang untuk mengkonstruksi dan mengadaptasikan pengetahuan. Sikap dan ketrampilan sesuai dengan pengalaman yang dimiliki dan konteks yang dihadapi.

Beberapa ahli menyatakan bahwa dalam situasi yang serba berubah perlu diantisipasi dengan pengembangan potensi dan kompetensi. Cattel dan Horn (2003), menyatakan pentingnya dua kemampuan pokok yaitu fluid inteligent (kemampaun dasar individu untuk mengembangkan fungsi intelektualnya tanpa terlalu dipengaruhi oleh proses belajarnya secara formal) dan crystalized inteligent (kemampuan intelektual individu yang pengembangannya sangat dipengaruhi oleh faktor belajar dan budaya). Dalam pandangan Gardner (Suparno, 
2004), perlu dikembangkan kecerdasan peserta didik bukan semata-mata kecerdasan intelektual (IQ). Namun perlu diintegrasikan dengan kecerdasan lain yang tergabung dalam multiple intelligent meliputi kecerdasan: linguistic, logical, spatial, musical, kinestetic, interpersonal, intrapersonal, dan naturalistic intelligent yang berfungsi secara independen dalam otak manusia. Stenberg (2002), mengidentifikasi pentingnya pengembangan kemampuan analitis, kreatif, dan praktis. Cullen (2003), menguraikan pentingnya kemampuan generic (transferable across occupational groups), vocational (spesific to job), basic (numeric, literacy), social and cultural, problem solving, productive (technical), normative (adaptability), dan innovative

Lingkungan bisnis global akan menjadi semakin kompleks, dinamis, dan bermunculan berbagai konflik kepentingan. Hard competence seperti pemahaman tentang bidang pekerjaan fungsional atau area tertentu, tidak lagi mencukupi bagi seorang tenaga kerja. Saat sekarang diperlukan tenaga kerja yang dididik secara liberal, memiliki pemikiran yang terintegrasi, komunikator yang handal, cerdas emosional, mampu bekerja dalam tim dan beretika, yang semuanya itu bersifat soft competence. Oleh karena itu, menjadi tantangan pendidikan untuk mengintegrasikan kedua macam komponen kompetensi tersebut secara terpadu dan tidak berat sebelah agar mampu menyiapkan SDM utuh yang memiliki kemampuan bekerja dan berkembang di masa depan.

Kehidupan di abad 21, Zamroni (2009), mengidentifikasi kompetensi yang diperlukan bagi kehidupan masyarakat yang mulkultural, antara lain: (1) memiliki integritas pribadi yang kokoh dengan memegang teguh etika bertanggung jawab bagi kemajuan masyarakatnya dan memegang teguh etika dalam perilaku pribadi dan profesionalnya; menjadi a learning person, senantiasa memperluas dan memperdalam pengetahuan dan kemampuan yang dimiliki; (3) memiliki kemampuan berkerjasama dengan segala perbedaan yang dimiliki; d)menguasai dan memanfaatkan ITC; dan (4) mampu mengambil keputusan yang senantiasa berlandaskan kepentingan masyarakat luas. Selaras dengan hal tersebut Kay (2008), menganalisis perkembangan yang akan terjadi di abad 21 dan mengidentifikasi kompetensi apa yang diperlukan dan menjadi tugas pendidikan untuk mempersiapkan warga negara dengan kompetensi tersebut. Terdapat 5 kondisi atau konteks baru dalam kehidupan berbangsa, yang masing-masing memerlukan kompetensi tertentu. Kondisi tersebut antara lain: (1) kondisi kompetisi global (perlu kesadaran global dan kemandirian), (2) kondisi kerjasama global (perlu kesadaran global, kemampuan bekerjasama, penguasaan ITC), (3) pertumbuhan informasi (perlu melek teknologi, critiacal thinking \& pemecahan masalah), (4) perkembangan kerja dan karier (perlu critical thinking \& pemecahan masalah, innovasi \& penyempurnaan, dan, fleksibel \& adaptable), 
(5) perkembangan ekonomi berbasis pelayanan jasa, knowledge economy (perlu melek informasi, critical thinking dan pemecahan masalah). Oleh karenanya, lembaga pendidikan harus mempersiapkan siswa dengan kemampuan: (1) kesadaran global, (2) watak kemandirian, (3) kemampuan bekerjasama secara global, (4) kemampuan menguasai ITC, (5) kemampuan melek teknologi, (6) kemampuan intelektual yang ditekankan pada critical thinking dan kemampuan memecahkan masalah, (7) kemampuan untuk melakukan innovasi \& menyempurnakan, dan, (8) memiliki pengetahuan dan ketrampilan yang bersifat fleksibel \& adaptabel.

Perubahan dan tuntutan karakteristik SDM era global menjadi tantangan lembaga pendidikan kejuruan untuk menyiapkan lulusannya agar mampu bertahan, bersaing dan meraih kejayaan. Relevansi kurikulum, pembelajaran dan penilaian dengan tuntutan SDM era global tersebut merupakan katakunci dalam mengembangkan pendidikan kejuruan ke depan. Penilaian memiliki peran strategis dalam menyiapkan SDM era global. Melalui penilaian dapat ditentukan apakah seseorang sudah dinyatakan layak dan kompeten atau belum. Penilaian dapat pula ditentukan apakah lulusan yang dihasilkan sesuai dengan tuntutan SDM masa depan yang memiliki daya siang tinggi.

Pentingnya perubahan paradigma penilaian dapat kita cermati dari ungkapan Linda Bonn, direktur bagian penilaian NCREL berikut: Assessment of student achievement is changing, largely because today's students face a world that will demand new knowledge and abilities. In the global economy of the 21st century, students will need to understand the basics, but also to think critically, to analyze, and to make inferences. Helping students develop these skills will require changes in assessment at the school and classroom level, as well as new approaches to large-scale, high-stakes assessment.

Merunut sejarah pengembangan dan penggunaan sistem penilaian di dunia pendidikan, dapat disimpulkan bahwa penilaian merupakan upaya sistematis yang dikembangkan oleh suatu institusi pendidikan yang ditujukan untuk menjamin tercapainya kualitas proses pendidikan serta kualitas kemampuan peserta didik sesuai dengan tujuan yang telah ditetapkan (Aiken, 1985, Anastasi, 1988, Buckendahl, 2002, Cullen, 2003). Proses penilaian digunakan sebagai sarana quality assurance. Sehingga peserta didik serta masyarakat pengguna jasa pendidikan diyakinkan melalui hasil penilaian bahwa output dari institusi pendidikan itu mempunyai kualitas yang sesuai dengan yang diharapkan.

Namun demikian, sering terdengar keluhan di masyarakat terhadap kualitas lulusan. Masyarakat sebagai penggunan jasa pendidikan sering menilai institusi pendidikan kurang mampu menghasilkan tenaga yang siap pakai. Masyarakat masih terbebani oleh kualitas lulusan yang demikian. Mereka harus mengalokasikan invest tambahan untuk mengolah 
kembali para lulusan tersebut sehingga siap pakai. Pada kasus lain banyak lulusan suatu lembaga pendidikan sulit memperoleh pekerjaan yang diinginkan karena jenis kemampuan dan keahlian yang dipunyai tidak sesuai dengan tuntutan pasar kerja. Karenanya banyak diantara mereka yang harus puas melakukan pekerjaan apasaja walaupun tidaks sesuai dengan kerangka disiplin ilmu yang telah mereka tekuni bertahun-tahun.

Bila permasalahan tersebut dikaji menurut sistem penilaian, dapat disimpulkan bahwa penilaian yang ada belum berfungsi sebagai sarana quality assurance. Fungsi penilaian terlihat belum terintegrasi ke dalam proses pengembangan kualitas pendidikan secara menyeluruh. Menjadi suatu tantangan bagaimana sistem penilaian mampu mendeteksi dan menilai potensi dan kompetensi peserta didik.

Permasalahan lain yang masih dihadapi dalam penilaian dan sering mendatangkan kritik tajam adalah adanya kesenjangan atau ketidaksesuaian antara penilaian yang dilakukan oleh guru di dalam kelas (classroom assessment) dengan penilaian yang dilakukan secara nasional atau dalam suatu daerah otonom tertentu (large scale assessment). Penilaian yang dilakukan guru di dalam kelas jelas bermaksud untuk memperbaiki proses pembelajaran yang sedang berlangsung. Asesmen dalam lingkup nasional berupa tes seleksi masuk lembaga pendidikan atau tes akhir suatu program pendidikan tertentu lebih bersifat memperoleh infromasi hasil pendidikan dengan memperbandingkan prestasi suatu lembaga dengan lembaga lain. Asesmen pendidikan nasional yang bersifat "large scale assessment" dimaksudkan sebagai pertanggung jawaban sistem pendidikan kepada masyarakat (akuntabilitas sosial pendidikan).

Salah satu sebab kesenjangan atau ketidaksesuaian classroom assessment dengan large scale assessment adalah dunia pendidikan saat ini yang lebih banyak memperhatikan large scale assessment daripada classroom assessment. Perhatian yang dimaksud untuk mendukung proses pembelajaran dan peningkatan hasil belajar peserta didik. Oleh karena itu, sudah saatnya bila perhatian mulai difokuskan pada upaya memperkuat dan meningkatkan peran classroom assessment dalam rangka meningkatkan kualitas pembelajaran dan kualitas lulusan. Melalui upaya ini diharapkan terjadi keselarasan dan kecocokan antara classroom asssessment dan large scale assessment.

\section{Penilaian sebagai Bagian Integral dari Proses Pembelajaran}

Kurikulum, proses pembelajaran, dan penilaian merupakan tiga dimensi dari sekian banyak dimensi yang sangat penting dalam pendidikan. Ketiga dimensi tersebut saling berkaitan antara satu dengan yang lainnya. Kurikulum merupakan penjabaran tujuan 
pendidikan yang menjadi landasan proses pembelajaran. Proses pembelajaran merupakan upaya yang dilakukan guru untuk mencapai tujuan yang dirumuskan dalam kurikulum.

Penilaian merupakan salahsatu kegiatan yang dilakukan untuk mengukur dan menilai tingkat pencapaian kurikulum. Penilaian juga digunakan untuk mengetahui kekuatan dan kelemahan yang ada dalam proses pembelajaran, sehingga dapat dijadikan dasar untuk pengambilan keputusan, misalnya apakah proses pembelajaran sudah baik dan dapat dilanjutkan atau masih perlu perbaikan dan penyempurnaan. Oleh sebab itu, disamping kurikulum yang cocok dan proses pembelajaran yang benar perlu ada sistem penilaian yang baik dan terencana.

Pasal 58 Undang-Undang No. 30 Tahun 2003 tentang Sistim Pendidikan Nasional dengan tegas menyatakan bahwa: evaluasi hasil belajar peserta didik dilakukan oleh pendidik untuk memantau proses, kemajuan, dan perbaikan hasil belajar peserta didik secara berkesinambungan. Mencermati pasal tersebut tampak bahwa pada dasarnya penilaian merupakan bagian integral dari proses pembelajaran, yang diarahkan untuk meningkatkan efektifitas pembelajaran. Pelaksanaan penilaian dan hasil belajar diarahkan untuk mengukur dan menilai performansi peserta diklat baik secara langsung pada saat peserta diklat melakukan aktivitas maupun secara tidak langsung melalui bukti hasil belajar (evidence of learning indicator) sesuai dengan kriteria unjuk kerja (performance critweria) yang ditetapkan. Penilaian hasil belajar peserta diklat menggunakan pendekatan penilaian acuan patokan (criterion reference assessment), dilaksanakan dengan prosedur dan mekanisme yang dapat mengembangkan sistem akuntabilitas jaminan kendali mutu (quality assurance dan quality control).

Pentingnya integrasi penilaian dengan pembelajaran dapat dicermati dari ungkapan Angelo: Classroom Assessment is a simple method faculty can use to collect feedback, early and often, on how well their students are learning what they are being taught. The purpose of classroom assessment is to provide faculty and students with information and insights needed to improve teaching effectiveness and learning quality. College instructors use feedback gleaned through Classroom Assessment to inform adjustments in their teaching. Faculty also shares feedback with students, using it to help them improve their learning strategies and study habits in order to become more independent, successful learners.... Classroom Assessment is one method of inquiry within the framework of Classroom Research, a broader approach to improving teaching and learning." 


\section{Classroom Assessment dalam Penyiapan Tenaga Kerja Holistik}

Perubahan kurikulum dari kurikulum berbasis isi (content-based curriculum) ke kurikulum berbasis kompetensi (competency-based curriculum). Perubahan pada tingkat satuan pendidikan mengakibatkan perubahan paradigma pada proses pembelajaran yaitu dari apa yang harus diajarkan (isi) menjadi apa yang harus dikuasai peserta didik (kompetensi). Perubahan kurikulum tersebut tidak hanya sekedar mengakibatkan terjadinya penyesuaian substansi materi. Tetapi juga terjadi pergeseran paradigma dari pendekatan pendidikan yasng berorientasi masukan (input-oriented education) ke pendekatan yang berorientasi hasil atau standar (outcome-based education). Perubahan tersebut juga membawa implikasi terhadap perubahan cara guru mengajar.

Perubahan kurikulum juga membawa perubahan dalam hal penilaian. Perubahan penilaian yang dimaksudkan adalah dari pendekatan norma ke penilaian yang menggunakan acuan kriteria, yaitu aspek yang menunjukkan seberapa kompeeten peserta didik menguasai materi yang telah diajarkan. Dalam konteks pembelajaran, penilaian merupakan kegiatan menghimpun fakta dan dokumen belajar peserta didik yang dapat dipercaya untuk melaksanakan perbaikan program pembelajaran. Oleh karena penilaian berfungsi membantu guru untuk merencanakan kurikulum dan program pembelajaran, maka kegiatan penilaian membutuhkan informasi bervariasi dari setiap individu dan atau kelompok peserta didik serta guru. Guru dapat melakukan penilaian dengan mengumpulkan informasi dan catatan dari pengamatan, pertemuan, portofolio, proyek, produk, ujian, interview, survey dan lainnya.

Penilaian kelas merupakan penilaian yang dilakukan guru dalam upaya meningkatkan kualitas poroses pembelajaran. Tujuan penilaian kelas adalah: (1) menjamin agar program pembelajaran tetap sesuai dengan kurikulum. Guru mengumpulkan informasi kemajuan belajar peserta didik melalui berbagai jenis penilaian kelas untuk memperoleh gambaran pencapaian kompetensi yang telah ditentukan dalam kurikulum, (2) memeriksa kelemahan dan kelebihan yang dimiliki peserta didik selama proses pembelajaran berlangsung, (3) mencari dan menemukan hal-hal yang menyebabkan terjadinya kelemahan dalam belajar, sehingga segera dapat diatasi, (4) menyimpulkan apakah peserta didik telah mencapai seluruh atau sebagian kompetensi yang telah ditentukan. Kesimpulan ini sangat penting sebagai laporan bagi stakehoolders seperti siswa, orangtua dan masyarakat. Sisi pedagogis penilaian bertujuan untuk: (1) mengevaluasi keberhasilan program pembelajaran, (2) menganalisis keberhasilan peserta didik dan mengidentifikasi kemungkinan kesalahan konsep, (3) menyajikan umpan balik (feed back) bagi guru sehingga dapat digunakan sebagai alat untuk mengembangkan program pembelajaran, (4) memotivasi belajar peserta didik dengan cara mengenal dan memahami diri dan merangsang untuk melakukan usaha perbaikan, (5) 
menyajikan informasi yang dapat digunakan untuk mengidentifikasi kesulitan belajar peserta didik, (6) mendiagnosis kesulitan belajar peserta didik, (7) menentukan kenaikan tingkat, dan (8) mengetahui ketercapaian mutu pendidikan secara umum.

Beberapa manfaat penilaian kelas antara lain: (1) memberi umpan balik pada program jangka pendek yang dilakukan oleh peserta didik dan guru dalam kegiatan pembelajaran sehingga memungkinkan melakukan koreksi, (2) memberi kegunaan hasil pembelajaran peserta didik dengan melibatkan peserta didik secara maksimal, dan (3) mendorong pengajaran sebagai proses penilaian formatif yang melibatkan banyak waktu untuk melakukan umpan balik dan perbaikan hasil peserta didik. Sedangkan bagi peserta didik, penilaian kelas sangat bermanfaat untuk (1) memantau pembelajaran dirinya secara lebih baik, (2) menitikberatkan pada kebutuhan perubahan kemampuan, keterampilan dan nilai. Bagi orang tua penilaian kelas sangat bermanfaat untuk (1) mengetahui kelemahan, kelebihan, dan peringkat anaknya, (2) mendorong orangtua peserta didik untuk melakukan bimbingan kepada anaknya, (3) melibatkan orangtua peserta didik untuk melakukan diskusi dengan guru/sekolahg dalam hal perbaikan kelemahan belajar pesreta didik.

Prinsip dalam menerapkan penilaian kelas antara lain: (1) tujuan program pembelajaran setiap mata pelajaran yang harus dicapai oleh peserta didik. Tujuan tersebut berupa standar kompetensi, kompetensi dasar dan indikator pencapaian hasil belajar; (2) standar keberhasilan yang harus dicapai peserta didik berdasarkan kriteria yang dijadikan rujukan; (3) penilaian kelas sebagai penilaian internal yang dilakukan guru merupakan bagian integral dari penilaian eksternal yang dilakukan oleh pihak lain seperti ujian akhir nasional. Penilaian eksternal diharapkan akan merujuk pada hasil penilaian internal. Obyektivitas penilaian eksternal akan sangat bergantung kepada penilaian internal, dan (4) model penilaian kelas menitikberatkan pada aspek perbaikan mutu pembelajaran dengan berpedoman pada rambu-rambu kurikulum

Dengan mencermati tujuan, manfaat, dan prinsip classroom assessment tersebut pertanyaan yang perlu dijawab adalah penilaian seperti apa yang sesuai dengan tuntutan pembelajaran dalam upaya mengahasilkan kualitas SDM masa depan secara holistik? Jawaban secara komprehensif dari pertanyaan tersebut dapat kita cermati dari karakteristik SDM era mendatang, kurikulum dan pembelajaran yang digunakan.

Berbagai penelitian dan literatur di atas jelas bahwa SDM yang dibutuhkan ke depan adalah SDM yang tidak hanya memiliki kemampuan yang kuat dalam aspek pekerjaan. Namun juga kemampaun dalam aspek lain yang dinamis. Kurikulum yang sesuai adalah kurikulum yang memfasilitasi lulusan untuk memiliki hard competence yang kuat dan soft competence yang dinamis. Standar kompetensi lulusan mencakup kemampuan berpikir, 
kemampuan psikomotor, dan kemampuan terkait dengan kepribadian. Hasil belajar peserta didik harus mencakup tiga aspek kemampuan yaitu berpikir yang terkait dengan aspek kognitif. Aspek psikomotor dan kepribadian yang terkait dengan aspek afektif. Untuk itu pembelajaran yang terjadi harus mencakup ketiga aspek kemampuan tersebut. Demikian pula sistem penilaiannya mencakup tiga aspek tersebut. Dengan demikaian, hasil belajar peserta didik diharapkan mencakup standar kompetensi.

Orientasi standar kompetensi tersebut selaras dengan karakteristik competence based training antara lain: (1) hasil belajar dinyatakan dengan kemampuan atau kompetensi yang dapat didemonstrasikan/ditampilkan, (2) semua peserta didik harus mencapai ketuntasan belajar yaitu menguasai semua kompetensi dasar, (3) kecepatan belajar peserta didik tidak sama, (4) penilaian menggunakan acuan kriteria, (5) ada program remidi, pengayaan, dan percepatan, (6) tenaga pengajar atau pendidik mereancang pengalaman belajar peserta didik, (7) tenaga pengajar sebagai fasilitator, dan (8) pembelajaran mencakup aspek afekrtif yang terintegrasi dalam semua bidang studi.

Selaras dengan paradigma kurikulum tersebut dewasa ini terdapat kecenderungan terjadinya pergeseran filosofi membelajaran, yaitu dari paradigma transmisi menuju pada aktivitas kelas yang berpusat pada pembelajar (Santyasa, 2004). Pergeseran filosofi tersebut berorientasi pada pembelajaran yang holistik yang memperhatikan perkembangan anak secara menyeluruh, meliputi pertumbuhan fisik, sosial, emosional, dan intelektual. Pembelajaran holistik akan memandu para praktisi pendidikan dalam memformulasikan pembelajaran secara lebih spesifik.

Memperhatikan karakteristik kurikulum dam pembelajaran tersebut dapat disimpulkan bahwa penilaian yang selaras dengan tuntutan tersebut adalh penilaian holistik yang mencakup pengembangan pribadi lulusan dari aspek kognitif, psikomotorik dan afektif. Langkah-langkah praktis dalam penilaian ketiga aspek tersebut dapat dijabarkan sebagai berikut:

\section{ANALISIS DAN PEMBAHASAN}

\section{Penilaian Aspek Kognitif}

Penguasaan peserta diklat dalam aspek pengetahuan dalam suatu pekerjaan merupakan aspek penting. Metode yang lazim digunakan dalam mengukur aspek ini adalah melalui tes tertulis dan lisan. Scott (1993:146), menjelaskan berbagai variasi yang mungkin dilakukan dalam mengembangkan tes tertulis yaitu: multiple-choice, sentence completion, listing, truefalse, matching, essay, dan modified form. Tujuan utama dalam penilaian aspek pengetahuan ini adalah guna mengembangkan proses pembelajaran, memberikan motivasi kepada peserta 
diklat, mendiagnosis kemampuan peserta diklat, mengembangkan pengajaran yang efektif, memecahkan masalah bersama guru dengan peserta diklat, dan memberikan informasi kepada peserta diklat untuk mengembangkan diri.

Hal yang perlu disiapkan oleh guru dalam merancang tes dalam aspek pengetahuan antara lain: (1) menentukan dan mengembangkan jumlah dan jenis item tes, (2) menentukan dan memilih tujuan yang akan diukur, (3) menganalisis tujuan dan menentuka isi tes, (4) mengembangkan garis besar isi untuk konstruksi item tes, (5) mengkonstruksi item tes, (6) membuat tabel perencanaan untuk memilih item tes. Tahapan dalam mengembangkan perangkat tes menurut Allen (1979: 118), antara lain:

1. Plan the test. Rumuskan tujuan tes yang akan dilakukan. Tujuan tes harus dirumuskan secara jelas sehingga memberikan arah dalam lingkup pengembangan tes selanjutnya. Setelah tujuan tes dirumuskan dibuatlah kisi-kisi (test blue-print/table of spesification).

2. Write item for each of the areas in the plan. Pernulisan soal adalah penjabaran indikator kompetensi yang hendak diukur menjadi pertanyaan-pertanyaan yang karakteristiknya sesuai dengan kisi-kisi. Setiap butir soal yang dibuat harus jelas apa yang ditanyakan dan jelas pula apa yang dituntut. Pada soal yang telah dibuat dilakukan review dan revisi orang lain atau ahli.

3. Administer all the items to a rasionably large sample of at least 50 (and preferably several hundred) examines. Soal yang telah direview dan direvisi secara tepritis merupakan soal yang baik. Guna memperoleh gambaran empirik perangkat tes perlu diujicoba pada kelompok subjek yang memiliki karaktersitik sama atau hampir sama dengan kelompok subjek.

4. Conduct an item analysis. Analisis item hasil ujicoba bertujuan untuk memperoleh informasi soal mana yang sudah baik, perlu direvisi atau diganti. Analisis dapat dilakukan dengan berbagai bantuan software pengolah data. Tes yang akan digunakan untuk menguji penguasaan kompetensi sebaiknya telah terkalibrasi berdasarkan tes modern.

5. Administer the revised test to another representative sample of examinee. Ujikan kembali tes yang sudah direvisi pada sampel lain yang memiliki karaktersitik sama atau hampir sama dengan karakteristik peserta tes yang akan diuji. Terhadap hasil tes, lakukan langkah ke-4 lagi. Hal ini disebut test standardization.

\section{Penilaian Aspek Psikomotor}

Penilaian penguasaan kompetensi aspek ketrampilan peserta diklat lebih cocok dilakukan dengan penilaian kinerja (performance assessment). Penilaian kinerja merupakan berbagai macam tugas dan situasi dimana peserta tes diminta untuk mendemonstrasikan 
pemahaman dan mengaplikasikan pengetahuan yang mendalam, serta ketrampilan di dalam berbagai nmacam konteks (Sriyono, 2003). Jadi performance assessment adalah penilaian yang meminta peserta tes untuk mendemonstrasikan dan mengaplikasikan pengetahuannya ke dalam berbagai macam konteks sesuai dengan kriteria yang diinginkan.

Guna mengevaluasi apakah penilaian kinerja sudah dianggap berkualitas, maka paling tidak harus diperhatikan tujuh kriteria yang dikemukakan oleh Popham (1995: 147), yaitu:

1. Generalizability, artinya apakah kinerja peserta tes dalam melakukan tugas yang diberikan tersebut sudah memadai untuk digeneralisasikan kepada tugas lain? Semakin dapat digeneralisasikan tugas yang diberikan dalam rangka penilaian ketrampilan atau penilaian kinerja tersebut atau semakin dapat dibandingkan dengan tugas yang lainnya, maka semakin baik tugas tersebut.

2. Authenticity, artinya apakah tugas yang diberikan tersebut sudah serupa dengan apa yang sering dihadapinya dalam praktek kehidupan sehari-hari.

3. Multiple foci, artinya apakah tugas yang diberikan kepada peserta tes sudah mengukur lebih dari satu kemampuan yang diinginkan.

4. Teachability, artinya apakah tugas yang diberikan merupakan tugas yang hasilnya semakin baik karena adanya usaha pembelajaran. Jadi tugas yang diberikan dalam penilaian ketrampilan atau penilaian kinerja adalah tugas yang relevan dengan yang dapat diajarkan guru.

5. Fairness, artinya apakah tugas yang diberikan sudah adil untuk semua peserta tes. Jadi tugas tersebut harus sudah dipikirkan tidak bias untuk semua jenis kelamin, suku bangsa, agama, atau status sosial.

6. Feasibility, artinya apakah tugas yang diberikan dalam penilaian ketrampilan atau penilaian kinerja memang relevan untuk dapat dilaksanakan mengingat faktor seperti baiaya, ruangan, waktu, dan peralatannya?

7. Scorability, artinya apakah tugas yang diberikan dapat diskor dengan akurat dan reliabel? Karena memang salahsatu yangs ensitif dari penilaian kinerja adalah pensekoran.

Beberapa tahap yang perlu dilakukan dalam mengembangkan penilaian kinerja yang baik, antara lain:

1. Identifikasi semua langkah penting yang pelu dilakukan atau yang akan mempengaruhi hasil akhir (output) yang terbaik.

2. Tuliskan perilaku kemampuan spesifik yang penting dan diperlukan untuk menyelesaikan tugas dan menghasilkan hasil akhir (output) yang terbaik.

3. Membuat kriteria kemampuan yang akan diukur tidak terlalu banyak agar semua kriteria dapat diobservasi selama peserta diklat melaksanakan tugas 
4. Definisikan dengan jelas kriteria kemampuan yang akan diukur berdasarkan kemampuan peserta diklat yang harus dapat diamati (observable) atau karakteristik produk yang dihasilkan.

5. Urutkan semua kriteria kemampuan berdasarkan urutan yang diamati.

6. Kalau ada periksa kembali dan bandingkan dengan kritertia kemampuan yang sudah dibuat sebelumnya oleh orang lain di lapangan.

Mengutip pendapat Frary (1995), Kehoe (1995), dan Moskal (2003), menyarankan tujuh langka dalam menyusun performance assessment dan rubrik. Ketujuh langkah tersebut antara lain: (1) writing goals and objectives, (2) developing performance assessments, (3) developing scoring rubrics, (4) administering performance assessments, (5) scoring, (6) interpreting, dan (7) using results. Dengan langkah tersebut diharapkan performance assessment dan rubrik yang disusun layak untuk diterapkan.

Beberapa cara menilai kemampuan keterampilan atau kemampuan kinerja (performance assessment) peserta tes dengan metode analitik antara lain adalah dengan cara menggunakan check list dan rating scale. Performance assessment dapat dilakukan dengan cara paling sederhana yaitu dengan menggunakan check list. Apabila kriteria kemampuan tertentu pada peserta diklat atau produk yang dihasilkan peserta diklat dapat diamati oleh penskor, maka peserta diklat tersebut mendapat skor dan apabila tidak, peserta diklat tersebut tidak mendapat skor.

Penilaian kinerja dengan rubrik dapat diimplementasikan dalam bentuk holistik atau analitik. Metode holistik digunakan apabila para penskor hanya memberikan satu buah skor (single rating) berdasarkan penilaian mereka secara keseluruhan dari hasil kinerja peserta diklat. Sedangkan dalam metode analitik, para penskor memberikan skor pada berbagai aspek yang berbeda yang berhubungan dengan kinerja yang dinilai.

Kesukaran yang paling utama ditemukan dalam performance assessment adalah penskoran. Menurut Popham (1995: 152), terdapat tiga sumber kesalahan (source of error) dalam performance assessment, yaitu:

1. Scoring-instrument flaws, instrumen pedoman penskoran tidak jelas sehingga sukar digunakan oleh penilai, umumnya karena komponen tersebut sukar untuk diamati (unobservable).

2. Procedural flaws, prosedur yang digunakan dalam performance assessment tidak baik sehingga mempengaruhi hasil penskoran.

3. Teachers' personal bias error, penskor (rater) sukar menghilangkan masalah personal bias, yakni ada kemungkinan penskor mempunyai masalah enerocity error artinya 
penskor cenderung memberi nilai yang tinggi. Walaupun hasil pekerjaan peserta tes tidak baik atau sebaliknya.

Masalah lain adalah kemungkinan terjadinya subyektivitas penskor sehingga sukar untuk memberi nilai yang objective. Guna memperkecil faktor subjektivitas keadilan dalam menilai kemampuan kinerja peserta diklat, biasanya rater jumlahnya lebih dari satu orang sehingga diharapkan hasil penilaian mereka menjadi lebih valid dan reliable. Kesalahan dari rater dapat diminimalkan apabila pedoman penskoran performance assessment dibuat dan didefinisikan sebaik mungkin dan juga sebelum dimulai penskoran diadakan pelatihan rater terlebih dahulu.

\section{Penilaian Aspek Afektif}

Sikap adalah kumpulan hasil evaluasi seseorang terhadap objek, orang, atau masalah terteentu. Kompetensi aspek sikap yang harus dicapai dalam pembelajaran meliputi rtingkat pemberian respon, apresiasi, penilaian, internalisasi. Penilaian aspek sikap sebaiknya lebih ditekankan kepada sikap kerja yang terintegrasi dalam pelaksanaan penilaian aspek ketrampilan, dengan tidak mengabaikan aspek sikap yang lain terkait dnegan aspek pembelajaran.

Tahapan dalam pengembangkan aspek sikap antara lain: (1) menentukan definisi konseptual atau konstruik yang akan diukur, (2) menentukan definisi operasional, (3) menentuka indikator, (4) menulis instrumen. Penilaian sikap dapat dilakukan dengan beberapa cara antara lain: observasi perilaku, pertanyaan langsung, laporan pribadi, maupun penggunaan skala sikap.

\section{Beberapa Catatan Penerapan Classroom Assessment dalam Proses Pembelajaran}

Dalam upaya untuk lebih mengoptimalkan proses pembelajaran beberapa catatan yang perlu diperhatikan dalam menerapkan classroom assessment, yaitu:

a. Kemampuan yang harus dimiliki Guru

Dalam upaya mengintegrasikan classroom assessment dalam proses pembelajaran, kemampuan penting yang harus dimiliki oleh guru adalah kemampuan untuk mengintegrasikan dan mensinkronkan penilaian yang dilakukannya. Hal tesebut sesuai dengan tujuan pembelajaran maupun kurikulum yang ditetapkan. Kemampuan lain yang perlu dikuasai adalah kemampauan teknis dalam hal menyusun instrumen, menilai kualitas instrumen, menyusun rubrik, menerapkan dan memanfaatkan data hasil 
pennilaian. Dengan dimilikinya kemampuan tersebut oleh guru menjadikan assessment is inherently a process of professional judgment.

b. Kualitas classroom assessment dan aspek lain

Aspek penting dalam penerapan classroom assessment adalah kualitas penilaian dan alat ukur yang digunakan. Kualitas tersebut menurt Bott (1996) antara lain: validity, reliability, descrimination, comprehensiveness, objectivity, dan practicability. Dengan demikian, alat ukur apa saja yang diterapkan harus sudah melampaui uji kualitas alat ukur. Selain aspek validitas (McMillan, 2000), menambahkan aspek lain yang menunjukkan suatu asesmen dinyatakan baik, antata lain: fair and ethical, use multiple methods, eficient and feasible, dan appropriately incorporates technology.

c. Alignment

Secara utuh keberhasilan proses pembelajaran dapat dinilai dari tiga dimensi yaitu pengetahuan, ketrampilan dan sikap. Ketiga dimensi tersebut sama pentingnya sebagai kesatuan yang holistik. Oleh karenanya, hasil belajar sebagai akibat proses pembelajaran harus dinilai secara menyeluruh dengan meliputi ketiga dimensi tersebut. Asesmen tersebut menjadi penting untuk mengukur semua aspek dalam pembelajaran kejuruan. Asesmen tersebut dilakukan untuk meyakinkan bahwa siswa dapat menunjukkan kemampuannya secara aktual dan menyeluruh dengan meliputi ketiga aspek setelah berlangsungnya proses pembelajaran. Faktor penting lain yang perlu dipertimbangkan adalah adalah alignment antara asesmen dan proses pembelajaran, karena kenyataan menunjukkan bahwa assessment driven teaching-learning process (Firman, 2003). Dengan demikian bila asesmen yang dilakukan telah meliputi tiga aspek pembelajaran kejuruan tersebut maka diharapkan pembelajaran juga melingkupi ketiga aspek tersebut.

Alignment refers to the degree of match between test content and the subject area content identified through state academic standards (Marca, 2001), mengemukakan bahwa alignment menyangkut dua dimensi, yaitu: content match (How well does test content match subject area content identified through state academic standards?) dan depth match (How well do test items match the knowledge and skills specified in the state standards in terms of cognitive complexity?). Dengan demikian, jelas bahwa asesmen yang disusun harus memenuhi aspek alignment baik content match maupun depth match.

d. Penilaian kelas sebagai alat meningkatkan motivasi belajar siswa

Motivasi merupakan faktor penting dalam proses pembelajaran. Oleh karenanya, penggunaan classroom assessment pada prinsipnya harus berperan dalam upaya meningkatkan motivasi dan membangkitkan kembali motivasi peserta didik dalam mengikuti proses pembelajaran dan bukan sebaliknya. Sebagai contoh, penelitian yang 
dilakukan Black and William (1998), menunjukkan bahwa penilaian kelas mampu meningkatkan motivasi belajar siswa.

e. Cooperative Assessment

Seiring dengan perubahan karakteristik dunia kerja pada era mendatang terjadi pergeseran dari paradigma kompetisi antar individu menjadi kerjasama tim. Oleh karenanya, pembelajaran lebih diorientasikan bagaimana menjalin kerjasama tim, problem based learning secara cooperative dan semacamnya. Dalam hal ini cooperative assessment merupakan disiplin yang layak dikaji.

f. Penyajian hasil penilaian

Penyajian atau pelaporan hasil penilaian pada masa lalu lebih berorientasi pada penilaian komposit dalam artian dengan pembobotan, setiap unsur baik kognitif, afektif, maupuin psikomotorik dijumlahkan kemudisn dibagi atau dirata-rata. Namun demikian dengan memperhatikan karakteristik yang berbeda dari masing-masing aspek. Penilaian dengan model komposit bukanlah pendekatan yang sesuai. Dalam hal ini, pelaporan hasil penilaian dengan profil merupakan pelaporan yang lebih rasional dan bermakna. Memlalui profil belajar siswa dapat diketahui kualitas dan kemampuan sesungguhnya dari peserta didik.

\section{KESIMPULAN}

Classroom assesment merupakan upaya efektif dalam upaya meningkatkan kualitas pembelajaran untuk mencapai tujuan dihasilkannya lulusan yang memiliki kemampuan kognitif, psikomotorik, dan afektif secara holistik sesuai tuntutan SDM dalam era global mendatang. Penilaian kinerja dengan rubrik ini dapat diimplementasikan dalam bentuk holistik atau analitik. Metode holistik digunakan penilaian secara keseluruhan dari hasil kinerja peserta didik.

\section{DAFTAR PUSTAKA}

Arends, I. (1997). Classroom Instruction and Management. New York: McGraw Hill.

Bott, Paul A. (1996) Testing and Assessment in Occupational and Technical Education. Boston: Allyn and Bacon.

Cullen, J. (2003). Competence evaluationand training for Europe. Retrieved December 15, 2006.

Himam, Fathul. (2004). Strategi Pengembangan Sistem Penilaian untuk Mendeteksi Potensi Peserta Didi. (Makalah) Yogyakarta: HEPI, Maret 2004.

Kay, K. (2008). Preparing Every Child for the 21st Century. APEC Ed Ne-Xi'an (Symposium) Xi'an China, January 17. 
La Marca, Paul M. (2001). Alignment of standards and assessments as an accountability criterion. Practical Assessment, Research \& Evaluation, 7 (21).

Linn, Robert L. and Gronlund, Norman E. (1995). Measurement and Assessment in Teaching. New Jersey: Prentice-Hall Inc.

McMillan, James H. (2000). Fundamental assessment principles for teachers and school administrators. Practical Assessment, Research \& Evaluation, 7(8). Retrieved December 15, 2006 from http://PAREonline.net/getvn.asp.

Mertler, Craig A. (2001). Designing scoring rubrics for your classroom. Practical Assessment, Research \& Evaluation, 7(25). Retrieved December 15, 2006 from http://PAREonline.net/getvn.asp?v=7\&n=25.

Moskal, Barbara M. (2000). Scoring rubrics: what, when and how? Practical Assessment, Research \& Evaluation, 7(3). Retrieved December 15, 2006 from http://PAREonline.net/getvn.asp?v=7\&n=3.

Moskal, Barbara M. (2003). Recommendations for developing classroom performance assessments and scoring rubrics. Practical Assessment, Research \& Evaluation, 8(14). Retrieved December 15, 2006 from http://PAREonline.net/getvn.asp?v=8\&n=14.

Nitko, Anthony J. (1996). Educational Assessment. New Jersey: Prentice-Hall, Inc.

Popham, W.J. (1995). Classroom Assessment: What Theachers Need to Know. Boston: Allyn and Bacon.

Roeber, Edward D. (1996). Guidelines for the development and management of performance assessments. Practical Assessment, Research \& Evaluation, 5(7). Retrieved December 15, 2006 from http://PAREonline.net/getvn.asp.

Rosyidin, Undang. (2004). Asesmen Otentik: Pengembangannya dan Penerapannya dalam Pembelajaran IPA. (Makalah) Yogyakarta: HEPI, Maret 2004.

Scott, Jhon L. (1993). Improving vocational curriculum: cognitive achievement evaluation. Illinois: The Goodheart-Wilcox Company, Inc.

Sriyono. (2004). Strategi Pengembangan Sistem Penilaian Berbasis Kompetensi Peserta Diklat Sekolah Menengah Kejuruan. Makalah Seminar Nasional Rekayasa Sistem Penilaian dalam Rangka Meningkatkan Kualitas Pendidikan. HEPI di Yogyakarta, Maret 2004.

Stiggins, R.J. (1994). Student Centered Classroom Assessment. New York: Maxwell Macmilan International.

Sukamto. (2001). Perubahan karakteristik dunia kerja dan revitalisasi pembelajaran dalam kurikulum pendidikan kejuruan. Pidato Pengukuhan Guru Besar. Yogyakarta: UNY.

Suparman, Atwi dan Zuhairi, Amin. (2003). Khasanah inovasi, difusi inovasi, dan implikasi inovasi terhadap kualitas pembelajaran. (Makalah) Yogyakarta: IPTPI, Agustus 2003. 
Suparno. (2004). Teori Inteligensi Ganda Howard Gardner. Yogyakarta: Kanisius.

Zainul, Asmawi. (2004) Asesmen Alternatif untuk Mendukung Belajar dan Pembelajaran. (Makalah) Yogyakarta: Himpunan Evaluasi Pendidikan Indonesia, Maret 2004.

Zamroni. (2009). Kebijakan peningkatan mutu sekolah di Indonesia. (Makalah). Yogyakarta: Universitas Negeri Yogyakarta di Auditorium Universitas Negeri Yogyakarta, April 2009. 